\title{
The rise of Western rationalism: Paul Feyerabend's story
}

Article

Accepted Version

Preston, J. (2016) The rise of Western rationalism: Paul Feyerabend's story. Studies in History and Philosophy of Science Part A, 57. pp. 79-86. ISSN 0039-3681 doi: https://doi.org/10.1016/j.shpsa.2015.11.013 Available at https://centaur.reading.ac.uk/38503/

It is advisable to refer to the publisher's version if you intend to cite from the work. See Guidance on citing.

To link to this article DOI: http://dx.doi.org/10.1016/j.shpsa.2015.11.013

Publisher: Elsevier

All outputs in CentAUR are protected by Intellectual Property Rights law, including copyright law. Copyright and IPR is retained by the creators or other copyright holders. Terms and conditions for use of this material are defined in the End User Agreement.

\section{www.reading.ac.uk/centaur}

\section{CentAUR}

Central Archive at the University of Reading

Reading's research outputs online 


\title{
The Rise of Western Rationalism:
}

\section{Paul Feyerabend's Story}

\section{John Preston}

\section{Department of Philosophy,}

The University of Reading,

\section{Reading RG6 6AA, UK}

\begin{abstract}
I summarise certain aspects of Paul Feyerabend's account of the development of Western rationalism, show the ways in which that account is supposed to run up against an alternative, that of Karl Popper, and then try to give a preliminary comparison of the two. My interest is primarily in whether what Feyerabend called his 'story' constitutes a possible history of our epistemic concepts and their trajectory. I express some grave reservations about that story, and about Feyerabend's framework, finding Popper's views less problematic here. However, I also suggest that one important aspect of Feyerabend's material, his treatment of religious belief, can be given an interpretation which makes it tenable, and perhaps preferable to a Popperian approach.
\end{abstract}

\section{Keywords}

Rationalism, science, Xenophanes, metaphilosophy, relativism, Popper

\section{Introduction}

While working on Against Method, Paul Feyerabend conceived a project he called 'The Rise of Western Rationalism'. ${ }^{1}$ At one point he seems to have intended this for publication in a single book, although it never came to fruition 
as such. Instead, parts of the material survive in his published articles, many of which have been brought together in the volumes Farewell to Reason (Feyerabend (1987)), and Conquest of Abundance (Feyerabend (1999)). The same themes are also touched upon in the lectures (from 1992) recently published under the title The Tyranny of Science (Feyerabend (2011)). But the seeds of some of the ideas I have in mind are already clearly present in Science in a Free Society, where we find this:

$[S]$ cience is not sacrosanct. The mere fact that it exists, is admired, has results is not sufficient for making it a measure of excellence. Modern science arose from global objections against what went on before and rationalism itself, the idea that there are general rules and standards for conducting our affairs, affairs of knowledge included, arose from global objections to commonsense (example: Xenophanes against Homer) (Feyerabend (1978), p.16).

This link between science and rationalism comes to assume great importance in Feyerabend's later work. Having already suggested that science gained the upper hand in history by force and trickery, rather than by virtue of any intrinsic superiority, the aim of this project, I think it can safely be said, would have been to show that 'rationalism' came to supersede previous ways of thinking in much the same way. '[T]he "Rise of Rationalism in the West", he put it in one of his last papers, 'shows the same kind of contempt towards nonbelievers that accompanied the rise of modern science' (Feyerabend (1995a) p.10, Feyerabend (1999), p.261)). (For more information on Feyerabend's motivations for engaging in such debates, see Helmut Heit's paper in this volume).

In this paper, I summarise some aspects of Feyerabend's account of the 
development of Western rationalism, show the ways in which that account is supposed to run up against an alternative, that of Karl Popper, and then try to give a preliminary comparison of the two, a comparison not of their fidelity to the ancient sources, but based on the conceptual tenability of their rival pictures. My interest is primarily in whether Feyerabend's story constitutes a possible history of our epistemic concepts and trajectory. I express some grave reservations about that story, and about Feyerabend's framework, but I also suggest that one important aspect of his material can be given an interpretation which may make it tenable.

\section{Knowledge in the Ancient World}

According to Feyerabend's potted history, life before the agrarian revolution (in the Neolithic era, circa 10,000 years ago) was really rather idyllic:

[E]very individual possessed all the knowledge and all the skills that were necessary for survival. Moreover, it took them only about two to four hours per week to take care of their necessities. Thus they could sit around, sing songs, philosophize or do whatever else seemed interesting and rewarding to them. ... The small groups of hunters and gatherers that roamed the countryside . . . collaborated in a fairly democratic manner (Feyerabend (1985), pp.155-6).

Even after the agrarian revolution, when skills became specialised, the epistemic situation didn't change much. Ancient navigators, craftsmen, farmers, etc., were familiar with a great variety of materials, plants, animals; they could identify and alleviate bodily and mental afflictions; they travelled across national boundaries and assimilated foreign ideas and techniques (Feyerabend 
(1993b), p.6 (Feyerabend (1999), p.265)). An enormous amount of information resided in their customs, industries, and in the common sense of the time. Acquiring knowledge was part of living. The knowledge acquired was 'relevant', and reflected personal and group concerns (Feyerabend (1987), p.4). It was not yet a commodity.

This somewhat romantic view of prehistory has not gone unchallenged by archaeologists. $^{2}$ However, other archaeologists are still willing to defend something like this view. ${ }^{3}$

A clearer picture of the situation emerges when literature comes on the scene.

\section{The Homeric Period}

In Hesiod's cosmology, the universe was originally formless ('Chaos'), and different powers battled to impose their own metaphysical-cum-social order onto things (as described in Theogony, and Works and Days). So there was no 'way the world is', but only different ways the world had been forced to be by divine and human agencies. ${ }^{4}$

Feyerabend presents the Homeric period as involving a related worldview, characterised by an aggregative metaphysic, part of which is already familiar to readers of the first edition of Against Method. ${ }^{5}$ According to this conception, the natural world, like the political world, is subdivided into regions which are subject to different (natural) laws (Feyerabend (1987), p.96). Gods, like humans, have their moirai, their allotted shares of the world. These are separated from each other, and qualitatively different. Thus the world at large comprises an aggregate with different divinities ruling over its different parts. But the aggregate character of the Homeric world was not restricted to the very large - it is found also in the smallest constituents. In this world, 
[t]here are no concepts that forge the human body and the human soul into a unit. There are no means of representation that would enable artists to give optical expression to such a unity. Both conceptually and optically, human beings are like rag dolls, sewed together from relatively isolated elements ... and functioning as transit stations for events (ideas, dreams, feelings) that may arise elsewhere and only briefly merge with a particular human being. Action in our sense does not exist in this world; a hero does not decide to bring about a certain event and then cause it, he finds himself involved in one series of events rather than in another and his life develops accordingly. All things, animals, carriages, cities, geographical regions, historical sequences, entire tribes are presented in this 'additive' manner - they are aggregates without 'essence' or 'substance' (Feyerabend (1987), p.97).

In his last works, Feyerabend extended his claims about the scope of this metaphysic even further. It applied, he suggested, not just to objects in the Homeric world, but also to the world-views of the Homeric Greeks and to the concepts which they used to evaluate their dealings with objects. The worldviews in question were eclectic and opportunistic. They exhibit no coherent knowledge, i.e., no comprehensive truth that goes beyond an enumeration of details, but there are many pieces of information, obtained in different ways from different sources, and collected for the benefit of the curious. The best way of presenting such knowledge is the list - and the oldest scientific works (the Babylonian-Assyrian word lists (Feyerabend (1995a), p.5)) were indeed collections of facts, parts, coincidences, and problems in several specialised domains. In the time of Hesiod, for example, truth consisted in 'a summation of individual reports' (Feyerabend (1984), p.97). ${ }^{6}$ (This, of course, is why Socrates continually runs into people who answer his 'What is ...?' questions 
by presenting lists). Although these lists contained an inner structure, their connecting principles were not explicitly formulated. That the gods themselves have complete knowledge does not mean that their gaze penetrates the surface to perceive a hidden unity beneath events, but only that they have the most complete lists at their disposal. The idea of a deeper unity lying behind phenomena is no part of this world view, according to Feyerabend. ${ }^{7}$

\section{The Demise of the Homeric World-View}

How does Feyerabend think this Homeric world-view was deposed? Most Greeks took the information contained in their trades and crafts for granted (Feyerabend (1993b), p.6 (Feyerabend (1999), p.265)). However, the social groups which prepared what is now known as Western rationalism and laid the intellectual foundations for Western science refused to take this abundance at face value (Feyerabend (1988b), pp.166-7). Aiming at something more profound, some of their early social critics, 'philosophers' (as they came to be called), started the work of knowledge all over again, this time without the details but with a maximum of generality. They denied that the world was as rich and knowledge as complex as the crafts and the commonsense of their time seemed to imply. These early 'rational' critics of tradition, says Feyerabend,

were religious reformers, for they heaped scorn on the traditional gods and replaced them with monsters. They were philosophers, for they preferred words to things, speculation to experience, principles to rules of thumb; and they did not mind when their ideas conflicted with tradition or with phenomena of the most obvious kind (Feyerabend (1993b), p.6, emphasis added (Feyerabend (1999), p.265)). 
They were also scientists of sorts (Feyerabend (1995b), p.806). And they were rather conceited, and motivated by power, rather than by truth. Being convinced of the superiority of their efforts, these thinkers deemed the opposing phenomena spurious and tradition worthless (Feyerabend (1993b), p.6 (Feyerabend (1999), p.265)). Their main offender was Xenophanes.

\section{Xenophanes}

Karl Popper's account of the pre-Socratics, and especially of Xenophanes, is one of Feyerabend's principal targets. ${ }^{8}$ Feyerabend agrees that Xenophanes counts as a forerunner of Popper's 'critical rationalism'; it's just that he considers this an indictment, rather than a compliment.

Let's remind ourselves of the important role that Xenophanes plays in Popper's account of the rise of rational thought. In his 1958 paper 'Back to the pre-Socratics', Popper conjectured that it was Thales who founded the new tradition of tolerating and encouraging criticism. This is what he calls 'the scientific or rational tradition' (Popper (1945), pp.122, 125) something that is both local and hard to transplant. Two generations later, Xenophanes, who brought the Ionian tradition to Elea (in Southern Italy), was the first philosopher to be fully conscious of the fact that 'all our knowledge was guesswork', and yet that 'we may nevertheless, by searching for that knowledge "which is the better", find it in the course of time' (Popper (1963), p. 152). Prefiguring Galileo and Einstein, Xenophanes not only understood this, 'the true theory of knowledge', but also realised that there is no such thing as induction (ibid.). He was the founder of the so-called 'sceptical' tradition whose later members include Socrates, Montaigne, and Hume (Popper (1992), p.192).

According to Feyerabend (who always used the classic Fragmente der Vorsokratiker (Diels \& Krantz 1903) as his source-book for such texts), 
Xenophanes not only opposed the cultural tendencies of his time, he is supposed to have revealed their foundations and criticised them (Feyerabend (1987), p.93). First, he criticised the idea that there are gods who resemble humans, who are cruel, angry and treacherous like epic heroes, and who influence history. The core of his negative theology, as we know it, his brief argument against polytheism, consists of the following fragments, quoted by both Feyerabend and Popper:

Everything humans despise and condemn and try to avoid, theft, and adultery, and lying deception of others Homer and Hesiod respectfully brought to the gods. (Fragments 11 \& 12).

The mortals consider that gods were created by birth that they wore clothes, had voices, and also a form. But if cattle, or lions, or horses had hands, just like humans; if they could paint with their hands, and draw and thus create pictures then the horses in drawing their gods would draw horses; and cattle would give us pictures and statues of cattle; and therefore each would picture the gods to resemble their own constitution. (Fragment 15).

Aethiopian gods - snubnosed and black

Thracians — blue-eyed and blond ... (Fragment 16). ${ }^{9}$

In sum: the old gods are immoral, and not praiseworthy (Fragments $11 \& 12$ ), they are anthropomorphic (Fragment 15), and they are ethnomorphic (Fragment 16). Maybe there is ridicule here, as Feyerabend contends, but it comes along 
with a moral and conceptual criticism: Homer and Hesiod are wrong to portray beings superior to us as sharing many of our worst faults, as well as the limitations of our species and the constitution of only one of our various races, their race.

Notice that this is not the most familiar argument against polytheism, which tries to reduce to absurdity the idea of a plurality of beings with supreme or unlimited power. (The 'absurdity' in question is not yet a contradiction, though, so could still fairly easily be clung onto). Feyerabend does make an important objection to such an argument against polytheism, which is that it is unsound (Feyerabend 1987, pp.95-99). ${ }^{10}$ That is, no believer in the Homeric pantheon would accept that each of their gods is credited with supreme or unlimited power, or that if one god had more power than another, the latter would not really be a god. Xenophanes' objection, though, is not fleshed out as this reductio, however much recent fans of his arguments would like it to have been.

Although Xenophanes is generally regarded as somewhat dilettantish (Feyerabend calls him 'a conceited bigmouth', albeit 'one with considerable charm' (Feyerabend (1987), p.91)), Feyerabend complains that this criticism of polytheism has been endorsed or favoured by many scholars who have little in common with each other. He notes that modern writers speak of Xenophanes' 'destructive criticism' (W. K. C. Guthrie), or 'acute criticism' (Mircea Eliade) of previous ideas. Xenophanes, says Hermann Fränkel (the German-American classical scholar), 'dared to reject the traditional tales as old inventions' (Fränkel (1960), p.341, translated as Fränkel (1974), p.121, and quoted in Feyerabend (1987), p.91). Finally, Popper reads the fragments as the 'discovery that the Greek stories of the gods were not to be taken seriously, because they represented the gods as human beings'; and he, too, speaks of a 'criticism' of existing ideas (Popper (1992), p.192, quoted on pp.94 \& 95 of Feyerabend 
(1987)).

According to Feyerabend, such later admirers claim that Xenophanes' critique led to the rise of rationalism. But if this is true, are Xenophanes' objections to traditional forms of thought really as penetrating and fertile as many philosophers believe? Do they really compel people to abandon the old anthropomorphic, ethnomorphic idea of gods who have human features and act in the world? Feyerabend argues that they don't. He set out to show what he called 'the basic dishonesty of all Rational philosophies', including Popper's. Their dishonesty is supposed to consist in the fact that they 'introduce strange assumptions which are neither plausible nor argued for, and then ridicule opponents for holding different views' (Feyerabend (1987), p.13).

\section{Xenophanes' Positive Theology}

Before we tackle this issue, let's recall that Xenophanes didn't just criticise the existing polytheism: a second part of his work comprises a positive theology (usually interpreted as monotheistic). The fragments in question are as follows:

One god alone is the greatest, the greatest of gods and of men not resembling the mortals, neither in shape nor in insight.

Always without any movement he remains in a single location as it would be unseemly to walk now to this, now to that place.

All of him sees, all of him knows, all of him hears.

But without effort, by insight alone, he moves all that is. (Fragments 23$6)$. 
Part of the burden of Feyerabend's case against modern 'rationalist' sympathisers is that this single god of Xenophanes' positive theology is in no way a clear improvement on its forerunners. For one thing, what he offers in their place is a creature that is still anthropomorphic, but 'far from human' (Feyerabend (1987), p. 95), in fact inhuman, in the sense that some of his human properties are monstrously increased, while other, 'balancing' features have been removed:

What we have is not a being that transcends humanity but a monster considerably more terrible than the slightly immoral Homeric gods could ever aspire to be. These one could still understand; one could speak to them, try to influence them, [etc]. There existed personal relations between the Homeric gods and the world they guided (and often disturbed). The God of Xenophanes, who still has human features, but enlarged in a grotesque manner, does not permit such relations. It is strange and .. . frightening to see with what enthusiasm many intellectuals embrace this monster, regarding it as a first step towards a 'more sublime' interpretation of divinity (Feyerabend (1987), p.95).

If this isn't merely a personal preference, then it's an ethical evaluation of the being that Xenophanes has in mind, rather than an epistemic evaluation of his reasons for postulating that being. Feyerabend didn't really accept that distinction, since he had come to think that views (including scientific views) should be evaluated only by ethical (or eudaimonistic) criteria. ${ }^{11}$ His arguments for that supposition are beyond my remit here; all I can say is that I think they are flawed. (If they were correct, the only kind of beliefs it would ever be acceptable to have would be beliefs that are conducive to human happiness or 
human flourishing).

Xenophanes' way of introducing this new god also arouses Feyerabend's anger. In introducing this strange creature, Xenophanes' dishonesty, according to Feyerabend, consisted in his taking advantage of certain new intellectual rules:

The God is introduced because Xenophanes can prove his most important properties. Not perception, not tradition, not the demands of piety determine these properties, but rather certain intellectual rules that were just discovered, and yet already act as judges over existence and nonexistence (Feyerabend (1984), p.104).

Feyerabend speculates that Xenophanes chooses this particular concept of god because it lends itself to proofs by reductio ad absurdum. That is, Feyerabend takes it that Xenophanes thinks he can show that the suppositions that the god is many, or that he came to be, or that his power is limited, lead to absurdities. But this 'because' can only be a speculation about Xenophanes' motives, since we have no evidence about those motives, and Xenophanes' negative theology (as Feyerabend presents it, at least) doesn't include such an argument. As an objection it would be merely ad hominem anyway, and would touch rationalism itself only if we think that acceptable views and procedures can only be introduced by people whose motives are pure.

\section{Feyerabend's Metaphilosophy}

Implicit in Feyerabend's comments about truth, proof, argument, reason, and reasons is a metaphilosophy, one which is made more explicit elsewhere, especially in The Tyranny of Science. According to this, proofs and arguments were simply "new kinds of stories, whose truth "followed from" their inner 
structure and needed no support from traditional authorities' (Feyerabend (1987), p. 66). In one frame of mind, Feyerabend himself declined to give arguments in favour of presenting 'stories' (hence the title of my paper); in another, he construed arguments as stories. But this metaphilosophy is deeply problematic. We can of course imagine people who don't do much by way of argument. But neither the rejection of all argument nor the construal of arguments as mere stories is even a possible human stance, for either of them would mean that one's stories, and beliefs, and thoughts, and their components had no non-contingent connections with one another. That kind of mind would be fragmented in exactly the way that only the most naïve empiricists think minds are: mere aggregates of thought-atoms, any combinations of which could hold at any moment with no implications for any other moment. One doesn't have to be a Kantian to want to avoid this view, to think that no human could really be entirely like that.

Nevertheless, even if we concede that Feyerabend is presenting a story rather than an argument, his story of the rise of rationalism can be addressed by critical arguments, and compared with other stories.

\section{Did Rationalism Triumph by Argument, or just by Rejection?}

Feyerabend then asks: when it comes to Xenophanes' negative theology, are we dealing with a criticism (which is what Popper calls it) or simply with a rejection of the idea of regional gods that share the properties of the region they dominate? And his answer is: the latter. The rejection becomes a criticism only if we can assume:

(A) that the concept of a god (or, more generally, that of a Truth or of a Being) which changes from one culture to the next is not valid anywhere or, conversely, that a fitting concept of a deity (or a fitting concept of 
truth or being) must be valid everywhere

and

(B) that the receiver of the criticism accepts (A), at least implicitly. Only then will the mockery hit its mark. Otherwise the opponent can say 'you are not speaking of our gods, but of an intellectual monster of your own invention which you use as a measure for all other gods. This has nothing to do with us'. (Feyerabend (1987), p.96).

Many modern authors praise Xenophanes for making assumption (A). Feyerabend accuses them of being insincere, since not all of them believe that the world is ordered by divine powers (Feyerabend (1987), p.96). But this accusation is unfair, since one doesn't have to believe that a single god exists in order to use Xenophanes' reductio against the idea of a plurality of gods. That is, (B) is wrong: its challenge is to Xenophanes' positive theology, not to his negative theology, against which it is ineffective. As a matter of fact 'the Milesians were unanimous in recognising the divine nature of their primary substances' (McKirahan (1994), p.60), but one could accept Xenophanes' criticism of polytheism without accepting his proof of monotheism. One could use it as an argument for atheism, for instance. (This would undermine the parallel between religion and epistemology on which Feyerabend is trading).

More importantly, though, Feyerabend insists that not everyone accepted proposition (A): there existed authors and entire cultures, both before and after Xenophanes, who explicitly denied it. Some of the most intelligent authors who wrote after him (Feyerabend cites Aeschylus, Sophocles, and Herodotus) 'either disregarded [Xenophanes] or went a different way' (Feyerabend (1987), p.98). However, neither their disregarding Xenophanes nor even their pursuing 
others sorts of enquiries yet means that these figures would, on reflection, have ('explicitly') denied (A), which is what Feyerabend needs here.

The nearest he gets to an example of this is Protagoras, whose relativism, Feyerabend claims, denies both assumptions of Xenophanes' 'argument', and thus agrees with basic principles of the Homeric world-view. Protagoras' doctrine, according to Feyerabend, 'was an exact mirror-image' of the world at that time (Feyerabend (1987), p.99). Now perhaps Protagoras is an example of someone who would have denied (A). Its typically relativist use of the term 'valid', makes that impossible to assess, though. This modern (specifically Californian?) concept of 'validity' is not one that Protagoras himself used.

Even if we ignore this, and concentrate on what we do know of Protagoras, further problems arise. His famous gnomic utterance 'Man is the measure of all things', which Feyerabend relies on heavily, is capable of being construed in different ways, not all of which are versions of relativism. Even if it expresses a version of relativism, the relativity may not be to individuals or cultures, as Feyerabend imagines, but to humanity as a whole. ${ }^{12}$ This would not give Feyerabend the example he needs, of someone who explicitly denies (A). And finally, even if Protagoras was exactly the kind of relativist Feyerabend imagines, we could still question whether he really used (rather than merely professed, in his philosophical moments) a relativist concept of truth. The best that can be said for Feyerabend's claim is that we cannot get close to knowing its truth: we cannot now say whether Protagoras would have regarded Xenophanes' criticism as an objection to polytheism.

When Feyerabend insists that assumptions (A) and (B) were not applicable to the Homeric world I also think he misses the evidence on the other side. The fact that the Greeks continued to pray to their own gods (rather than any local gods) when they were trading or fighting abroad suggests that 
they did accept (A). When travelling in Ethiopia, for example, there is no reason to think that Thracians would have there worshipped (only) snub-nosed black gods, and no red-haired blue-eyed ones. It is true that the Greek gods had their moirai, but these are of the other kind Feyerabend mentions, not of the kind he imagines here. That is, they are cosmological domains such as the sea, the underworld, Mount Olympus, etc., rather than human geographical domains. The issue that Feyerabend identifies doesn't arise with the cosmological domains because the gods who are their denizens are members of a cohort of deities, not alternatives to one another.

\section{Feyerabend's Initial 'Relativistic' Account of the how the Transition was Effected}

As we saw, Feyerabend thought rationalism and science conquered their opponents either by force, or by fraud, and that they could only have triumphed in this way. At first, anyway, his own account involves what he identifies as 'the relativistic idea that the popularity of philosophical positions is a result of power (or deception), not of argument' (Feyerabend (1987), p.99). The fact that by now many intellectuals regard theoretical, or 'objective' knowledge as the only knowledge worth considering is a conceit which would have substance, he supposes, only if scientists and philosophers looking for universal and objective knowledge and a universal and objective morality had succeeded in finding the former and convinced, rather than forced, dissenting cultures to adopt the latter. But according to Feyerabend this is not the case. "[T]he regionalism of phenomena was never overcome, neither by philosophers, nor by scientists, while the regionalism of social phenomena was repressed or destroyed by violence, not shown to be inadequate by ethical reasoning' (Feyerabend (1987), p.100, emphasis in the original; see also ibid., p.168, and Feyerabend (1986), p.99). 
Feyerabend never made a convincing case for this idea that the social change in question was an exercise of force de majeure. He never presented any evidence that this was the case, as far as I can see. Even his more promising idea that it was a con-trick is problematic. Certainly he did nothing to show how defenders of the ancient pantheon of Gods might have rebutted (rather than merely ignored) Xenophanes' objection. It's quite true that theoretical knowledge is not the only kind of knowledge worthy of the name, and that some rationalists (including Popper, I think) are wrong to forget this. But overall, as I shall now argue, Popper's account of the pre-Socratics and the transition to 'rationalism' is preferable to Feyerabend's.

\section{Institutionalisation of the Critical Attitude}

For Popper, what the pre-Socratics did was to socially firm up and canonise or institutionalise an attitude that humans can always potentially take towards beliefs and their evaluation, the critical (or scientific, or for Popper the 'rational') attitude. If Popper is right, this was the first time that such an attitude was institutionalised. (That seems plausible - we know of no previous sequence of ideas like the pre-Socratic sequence).

Feyerabend, though, contends that the rise of Western rationalism was the result of a discovery, the discovery of 'certain intellectual rules' (Feyerabend (1984), p.104), or the discovery that concepts can be connected in special ways, called 'arguments' (Feyerabend (1978), p.53).

This can't be right. The attitude in question, the critical attitude, is one that humans could (at least in principle, if not in terms of social possibility) have taken prior to Thales, and which is humanly possible in any culture. For this attitude is routinely taken every day in evaluating the (non-theoretical, noncosmological, non-philosophical and non-religious) beliefs of one's fellow human beings. Logic has a history, of course. But Xenophanes' argument relies 
on no more than reductio ad absurdum, and this mode of argument is implicit (even if not explicit) in any human way of life. That is, all socialised adult humans are capable of having thought-sequences of the form 'What if $\mathrm{X}$ was the case? Well, that would mean that $\mathrm{Y}$ would also be the case. But $\mathrm{Y}$ isn't the case, or is absurd, or otherwise untenable. So X can't be the case'.

Feyerabend is denying this (which I think is only one component in a Kantian conception of the unity of humanity), and I think we ought not to follow him. He argued that Xenophanes et al. introduced to humanity 'rational' methods of argument per se. On that supposition, he would certainly have had a point against Popper: that would have to have been a trick or an exercise of force. Here we run up against one of the limits of rationality, as it were: one can't successfully argue someone into accepting or joining the rationalist tradition, since to do so would presuppose that they were already responsive to argument (and thus already part of that tradition).

Feyerabend's idea that the transition to rationalism was a con-trick also faces the problem that Xenophanes may have been pointing out to those already in the sequence (among others) that their beliefs about gods can be evaluated in the same way as they already evaluated their own and others' beliefs about physical cosmology, and that when one does so, they are revealed as problematic. Feyerabend here follows the usual supposition that Xenophanes' argument against the Homeric gods is the first example of reductio. But this need not be right. As Popper suggests (Popper (1963), p.139), Xenophanes' predecessor Anaximander may well already have argued against the cosmology of his predecessor, Thales, in just this way. That is, to Thales' claim that the earth is floating on water, Anaximander may have objected that this would involve an infinite regress, which is an absurdity. In this way he might have come up with his own cosmological idea, according to which the 
earth remains where it is because it is equally distant from all other cosmological things.

\section{From Religion to Relativism?}

Even if in his description of the ancients, Feyerabend can show that gods were regarded as having their allotted shares in the world of the geographical kind he imagines (which I have denied), he makes little attempt to show that the same thesis makes sense when transposed from the religious into the epistemological or metaphysical key. More generally and significantly, he relies on a dubious transition from the religious to the epistemological. There may be parallels between the concept of god and concepts which express epistemic ideals, but to note this is not to show that ancient people had a concept of truth or of reality according to which what is true or what is real can vary from one culture to the next. Epistemic concepts are not on a par with religious concepts in this respect: even if all parties to the debate did understand what it means to deny that there is a single god (the concept of a god at that time had this kind of flexibility built-in), it has not been shown that they understood what it would be for there to be a plurality of incompatible truths, that is, what it would have been for a relativist concept of truth to be operative. Feyerabend reads his own preferred perspective on epistemic concepts (the one he calls 'the relativism of Protagoras', or 'Protagorean relativism' (Feyerabend (1987), p.99, Feyerabend (1993a), pp.187-8)) back into the thoughts of these people too swiftly, and with insufficient justification. He doesn't give any evidence that the ancients (not just Protagoras, but laypeople) would really have accepted statements of the form 'While $p$ is true for me, not$p$ is true for you'.

\section{Feyerabend's Incredible Homeric Greeks}


It is true that the way in which Popper writes makes the pre-Socratic thinkers seem like the well-behaved participants in a mid-twentieth century logic class (Logic \& Cosmology 101, perhaps). But although Popper's preSocratics aren't quite weird enough, this cuts only shallowly against him, since he could easily concede that the pre-Socratics were stranger than he presented them as being. All he needs is that they had the sequence of thoughts in question, and somehow generated the social tradition he has in mind. Feyerabend's Homeric Greeks, though, are too weird. As I shall now argue, this cuts deeply against Feyerabend, for his Greeks aren't even possible people.

The book Feyerabend mainly relied on in his account of the Homeric Greeks is The Discovery of the Mind (German original, 1948), in which German classical philologist Bruno Snell suggested that Homer's characters are different kinds of people from us, with no sense of inner conflict in decisionmaking, and thus no inner core of identity.

As regards Homer's epics these claims are now widely regarded as having been discredited, since various people, including Bernard Williams (in his Sather Lectures, delivered at the University of Berkeley in 1989 and subsequently published as Shame and Necessity (Williams (1993)), have been able to find passages in Homer that give very clear evidence of characters being in inner conflict when deliberating about decisions. Perhaps Feyerabend attended these lectures, for he referred to them in a footnote to Conquest of Abundance (Feyerabend (1999), p.25, note 12), and conceded the point. What remains is, as he puts it, "that "Homeric Man" has less coherence and is less separated from (or better integrated into) his surroundings than the "autonomous individual" of later times'. This may be true, but it isn't enough to re-condition his argument.

Feyerabend's versions of Snell's claims are also problematic when understood as claims not merely about Homeric characters, but about all Greeks 
at that time. That the burden of proof here is on him, rather than his opponents, I think is clear. Modern philosophers like Kant, Strawson, Quine and Davidson supply us with a priori arguments for supposing that the Homeric world-view simply couldn't have been as different from ours in these fundamental respects as Feyerabend supposes. Feyerabend's Homeric Greeks are, after all, very strange indeed.

For example, one ought to be very suspicious of his idea that action simply didn't exist in the Homeric world. There are, it is true, people who think of themselves as instruments (of God's will, for example). But it is impossible to imagine people who don't conceive of themselves as agents at all. Thinking of a person as merely a 'transit station' (Feyerabend (1987), p. 97) for externally-induced phenomena would be to make nonsense of their assertions, including the assertion that they were not genuine agents or authors of their own actions. Attempting to think of oneself like that would prevent the application not just of the concept of action but also of the concept of thought (because thinking is itself an activity). There is a kind of (pragmatic?) selfvitiation here, and that should be enough to force us to re-think this view, even if it seems to be suggested by the literature.

Another of Feyerabend's suppositions clearly amounts to the contention that these people just didn't have the concept of a person. This would have to be stacked up not only against Peter Strawson's argument that this concept is primitive relative to the concepts of mind and body, but also to mountains of anthropological data. A further conflict with Strawson's perspective emerges when we consider that Feyerabend presents these folk as having the concept of experiences (or even perhaps that of sense-data?) prior to that of material objects).

Finally, Feyerabend's account of Xenophanes' argument presupposes that the Greeks had the concept of belief (opinion) before they had the concept 
of truth. But one doesn't need Donald Davidson to see that, for creatures with a language, at least, having the concept of belief requires having the concept of (objective) truth. Why? Because believing that $p$ is believing that $p$ is the case. Assumptions (A) and (B) are therefore rehabilitated, at least insofar as they apply to the concept of truth. (Feyerabend would not, of course, have been impressed by such a priori philosophical considerations. But to take the anthropological accounts which violate them at face value would represent a hopelessly uncritical, indeed thoughtless, empiricism).

\section{The Origin of Philosophy}

By contrast with Feyerabend's story, Popper's idea that Thales initiated the new institution he had in mind, the tradition of critical discussion of one's own theoretical views, as well as the theoretical views of others, is not only possible, but plausible. For Popper what is important is that science starts thus, with the pre-Socratics. Not being as persuaded that science really involves criticism to the extent that Popper would like, I would rather stress that it's philosophy that starts thus. That is, what we (in the West) fully recognise as philosophy begins with the pre-Socratics (not startling news, I know). Prior to Thales there are, of course, first-order ideas, including cosmologies, but there is not (as far as we know) the second-order tradition that Popper had in mind, the tradition not merely of allowing but of encouraging the critical evaluation of first-order ideas (Popper (1963), p.127). (When the tradition of evaluating second-order ideas begins is another question, of course. That's not necessarily with Thales). There can be no objection to calling this 'rationalism' if one wants to do so (as Popper does). I would not follow anyone who thought this was the beginning of rationality itself (as if we had to say that Thales was the first rational being!), but Popper doesn't have to say that. What Thales founded was an institution that encapsulated and amplified something whose possibility 
already characterised human lives, critical discussion. I personally wouldn't call this the first rational institution, since I'm not wedded as exclusively to critical rationality as Popper was. But I agree with him that it's the start of something important, and something that all human beings have the prerequisites for - the critical component of philosophizing and science.

\section{Feyerabend on Philosophy}

Perhaps this gives us a clue to why Feyerabend, in his later life, was deeply ambivalent about philosophy itself. More than once he explicitly denied that he was a philosopher (Feyerabend (1993)). In a way, he put himself and saw himself outside one very important component of the academic philosophical tradition, an overtly critical component, the component that insists that first-order ideas, wherever they come from and whatever their social backing, can and indeed should be evaluated, at least in part by considering what can be said against them. However, this doesn't mean that he really escaped the philosophical tradition. For it's also notable that he was still quite prepared to take this critical attitude towards second-order ideas, such as the ideas of philosophers and other intellectuals. (This is surely another aspect of his distrust of intellectuals).

Again, I find this problematic, since I'm not sure that there is a stable 'position' to be had here (noli tangere when it comes to first-order ideas, or the ideas of laypeople, the complete opposite when it comes to second-order ideas, or those of intellectuals). For one thing, I'm not sure that the distinctions which I've been working with (like first-order/second-order, and laypeople/intellectuals) are anything more than rough-and-ready. But while I'm well aware that Feyerabend might not have cared at all about there not being a stable position here, $I$ care about it. 


\section{What Feyerabend Might have Meant (or said): the Bifurcated Path}

Nevertheless, I think Feyerabend is quite right that those on the receiving end of Xenophanes' criticisms could have insulated their beliefs against them. Xenophanes' argument, after all, targets a particular kind of belief, not commonsense beliefs (as Feyerabend says sometimes), but religious beliefs (as he elsewhere recognises). One can quite well impose a bifurcation between such matters and others, since one can quite well think that religious beliefs are beliefs of a distinctive kind. That is, Feyerabend might have meant (or might have argued) that the apparatus of reason (here, logic and methodology) cannot, or should not, be applied to these matters (or should be applied only to some diminished extent). This, too, would be to follow a significant philosophical tradition. One thinks, for example, of Kant's claim that setting the limits of reason makes room for faith. Or of Wittgenstein's philosophy of religion, in which it is denied that religious beliefs are theoretical beliefs. This tradition even has its representatives in science (Stephen Jay Gould's portrayal of science and religion as 'non-overlapping magisteria'). Here I think Wittgenstein's line has something going for it, in that it allows that religious beliefs are beliefs, but insists that they aren't theories, and thus that they can't be evaluated for theoretical truth/falsity. To be a religious believer is, as he once put it, to have 'a passionate commitment to a system of reference' (Wittgenstein (1980), p.64).

To take any such line is to insulate religion from the full glare of the apparatus of reason (critical and otherwise). And this seems to be the dominant strand in the accommodation to which we are coming in contemporary Western societies. It means, though, that one can't even start down the path that Xenophanes trod. One can't follow him even in regarding monotheistic religions as being rationally preferable to polytheistic ones. Much further than this, though, it means that in matters of religious belief, as one might put it, 
anything goes. So whether I worship God, Allah, Zeus, Amon Ra, Thor, Vishnu, Satan, or any combination of the above, whether I think Jesus Christ was a troublemaker, a prophet (but not the last prophet), the Son of God, or the first incarnation of the Emperor Haile Selassie, or whether even, in the final analysis, I worship an invisible intangible whatnot, my beliefs are intellectually and socially protected. As long as I can persuade others that I really consider the things I worship to have some spiritual power, and as long as I declare that these are my deeply-felt convictions, they are protected from public evaluation by others except in eudaimonistic terms. Rationalists can think what they want about them (although they can't now say it, in the UK, at least), but their estimation of my religious beliefs isn't allowed to affect whether I can continue to believe them, promote them, etc. Insofar as Feyerabend was adverting to the possibility, perhaps even the desirability, of such a bifurcation, he's right.

So, when one bears in mind what Popper means by 'rational' (i.e., accompanied by a second-order critical tradition), the claim that there is no acceptable alternative to being 'rational' is just the kind of thing that Feyerabend would challenge, and when it comes to religious belief the challenge has some merit. Not only can humans proceed in this way, this is the path we are now taking.

I won't say that I think this is the line that Feyerabend should have taken. Personally, I suppose I'm too much of a rationalist, and not sympathetic enough to religious belief of any kind. I think one can quite well start down Xenophanes' path, and that when one does so one gets quite quickly to something Feyerabend seems to have despised - 'the God of the philosophers', and then beyond this to agnosticism, if not to atheism.

\section{Better than Relativism}


I $d o$ think, though, that this bifurcated path has a distinct advantage over relativism, since I agree with Popper that relativism about truth is untenable. When applied to religious belief, the idea that one thing is true 'for me', another true 'for you' is either merely a version of the view I have outlined (in which 'true for X' just means that it's X's belief), or it's a charade, that is, an attempt to use the concept of truth in a certain way, but a way in which the concept doesn't allow. Of course, Feyerabend would point out that concepts are ambiguous and flexible, and they can be altered. But different concepts are ambiguous and flexible to different degrees, and I'm not as convinced as Feyerabend that the concept of truth is flexible in this way. It's true that concepts can be altered, but there must be a pressing reason to do so, and because the bifurcated position I have sketched is available, I can't see any reason to mangle the concept of truth in the way the relativist wants.

\section{Rejecting Rationality Entirely?}

In giving Feyerabend the option of this bifurcated path, I have not capitulated in any way to the suggestion that the apparatus of rationality shouldn't be applied in science. Sometimes Feyerabend really is suggesting this, I think, and I don't want to follow him down that road.

\section{Acknowledgements}

This paper is very much a preliminary investigation into a wealth of Feyerabend material, and it does not take into account Feyerabend's posthumously-published book Naturphilosophie (Feyerabend 2009), the material for which he had worked on for many years. For comments on this paper, I am grateful to members of the audience at meetings of the British Society for the Philosophy of Science, Manchester University's Mind \& Society Group, a seminar at the IMT Institute for Advanced Studies, Lucca, and 
the Feyerabend 2012 conference at Humboldt University, Berlin, to whom it was presented, as well as to Ana Esteve Fernandez, for conversations on the relevant Feyerabend papers.

\section{References}

Arkush E. N. \& Allen, M. W. (eds.), (2006) The Archaeology of Warfare: Prehistories of Raiding and Conquest. Florida: Florida University Press.

Diels, H. \& Krantz, W. (1903) Die Fragmente der Vorsokratiker. Berlin: Weidmann.

Feyerabend, P. K. (1975) Against Method. London: Verso.

Feyerabend, P. K. (1978) Science in a Free Society. London: New Left Books. Feyerabend, P. K. (1981) Realism, Rationalism, and Scientific Method: Philosophical Papers, Volume 1. Cambridge: Cambridge University Press.

Feyerabend, P. K. (1984) Xenophanes: A Forerunner of Critical Rationalism?, in G. Andersson (ed.), Rationality in Science and in Politics (pp.95-109) Dordrecht: D. Reidel.

Feyerabend, P. K. (1985) Galileo and the Tyranny of Truth, in C. V. Coyne, M. Heller, \& J. Zycinski (eds.), The Galileo Affair: A Meeting of Faith and Science (pp.155-166) Rome: Vatican City.

Feyerabend, P. K. (1986) Trivializing Knowledge: A Review of Popper's Postscript, Inquiry, 29, 93-119.

Feyerabend, P. K. (1987) Farewell to Reason. London: Verso.

Feyerabend, P. K. (1988a) Against Method. $2^{\text {nd }}$ edition, London: Verso.

Feyerabend, P. K. (1988b) Knowledge and the Role of Theories, Philosophy of the Social Sciences, 18, 157-178.

Feyerabend, P. K. (1991) Three Dialogues on Knowledge. Oxford: Blackwell. Feyerabend, P. K. (1992) Ethics as a Measure of Scientific Truth, in W. R. Shea 
\& A. Spadafora (eds.), From the Twilight of Probability: Ethics and Politics (pp.106-114) Canton, MA: Science History Publications.

Feyerabend, P. K. (1993a) The End of Epistemology?, in J. Earman et al. (eds.), Philosophical Problems of the Internal and External Worlds: Essays on the Philosophy of Adolf Grünbaum (pp.187-204) Pittsburgh: University of Pittsburgh Press.

Feyerabend, P. K. (1993b) Intellectuals and the Facts of Life, Common Knowledge, 3, 6-9.

Feyerabend, P. K. (1994a) Has the Scientific View of the World a Special Status, Compared with Other Views?, in J. Hilgevoord (ed.), Physics and Our View of the World (pp.135-148) Cambridge: Cambridge University Press.

Feyerabend, P. K. (1994b) Realism, in C. C. Gould \& R. S. Cohen (eds.), Artifacts, Representations and Social Practices (pp.205-222) Dordrecht: Kluwer.

Feyerabend, P. K. (1994c) Potentially Every Culture Is All Cultures, Common Knowledge, 4, 16-22.

Feyerabend, P. K. (1995a) Universals as Tyrants and as Mediators, in I. C.

Jarvie \& N. Laor (eds.), Critical Rationalism, Metaphysics and Science. Essays for Joseph Agassi, Volume 1 (pp.3-14) Dordrecht: Kluwer.

Feyerabend, P. K. (1995b) Science, History of the Philosophy of, in T. Honderich (ed.), The Oxford Companion to Philosophy (pp.806-809) Oxford: Oxford University Press.

Feyerabend, P. K. (1999) The Conquest of Abundance. ed. B. Terpstra, Chicago: University of Chicago Press.

Feyerabend, P. K. (2009) Naturphilosophie. ed. H. Heit \& E. Oberheim, Frankfurt: Suhrkamp Verlag.

Feyerabend, P. K. (2011) The Tyranny of Science. ed. E. Oberheim, Cambridge: 
Polity Press.

Fränkel, H. (1960) Wege und Formen Frühgriechischen Denkens: literarische und philosophiegeschichtliche Studien. Ed. F. Tietze, Munich: C. H. Beck.

Fränkel, H. (1974) Xenophanes' Empiricism and His Critique of Knowledge (B34), in A. P. D. Mourelatos (ed.), The Pre-Socratics: A Collection of Critical Essays (pp.118-131) New York: Anchor Books.

Gardner, M. (1982-3) Anti-Science: The Strange Case of Paul Feyerabend, Free Inquiry, 3, 32-34.

Keeley, L. H. (1996) War before Civilization. Oxford: Oxford University Press. Leblanc, S. A. (2003) Constant Battles: The Myth of the Peaceful, Noble Savage. New York: St. Martin's Press.

McKirahan, R. D. (1994) Philosophy before Socrates. Indianapolis: Hackett.

Motterlini, M. (ed.) (1999) For and Against Method, including Lakatos's Lectures on Scientific Method, and the Lakatos-Feyerabend Correspondence. Chicago: University of Chicago Press, 1999.

Munevar, G. (2002) Conquering Feyerabend's Conquest of Abundance, Philosophy of Science, 69, 519-35.

Popper, K. R. (1945) The Open Society and Its Enemies. London: Routledge.

(1963) Conjectures and Refutations: The Growth of Scientific Knowledge. London: Routledge.

(1992) In Search of a Better World: Lectures and Essays from Thirty Years. London: Routledge.

Preston, J. M. (1992) On Some Objections to Relativism, Ratio, 5, 57-73.

Turner, R. (ed.), (1987) Thinkers of the Twentieth Century. Chicago \& London: St. James Press.

Williams, B. A. O. (1993) Shame and Necessity. Berkeley: University of California Press. 
Wilson, E. O. (2012) The Social Conquest of Earth. New York: W. W. Norton. Wittgenstein, L. (1980) Culture and Value. Oxford: Blackwell.

${ }^{1}$ See the entry on Feyerabend in Turner (1987), p. 227. In 1982, Martin Gardner mentioned that the book, although 'eagerly awaited', had not yet been published (Gardner (1982-3)), p.32.

${ }^{2}$ For literature critical of this romantic view, see Keeley (1996), LeBlanc (2003), and works by Samuel Bowles, detailed in Wilson (2012).

${ }^{3}$ See, for example, Brian Ferguson's essay in Arkush \& Allen (2006).

${ }^{4}$ I am grateful to an anonymous referee for impressing upon me the importance of this preHomeric phase. The up-for-grabs nature of Hesiod's reality clearly chimes with Feyerabend's own conception.

${ }^{5}$ Feyerabend (1975), chapter 17, especially pp. 232-49 and 260-77. Although this chapter is not reproduced in later editions of Against Method, this is emphatically not because Feyerabend disowned it.

${ }^{6}$ The fact that truths can be presented in a list, surely doesn't mean that truth $=$ list, though.

${ }^{7}$ See especially Feyerabend (2011), pp.16, 38, 58, 102.

${ }^{8}$ For more on their relationship, see the papers in this volume by Helmut Heit and Matteo Collodel.

${ }^{9}$ These are the passages in Feyerabend's translation, quoted from Feyerabend (1999), p.51. Popper's version occurs in his (1963), pp.152-3.

${ }^{10}$ Here I am grateful to Gonzalo Munevar, who reminded me of this in discussion. See also his Munevar (2002).

${ }^{11}$ See, for example, Feyerabend (1992).

${ }^{12}$ See Preston (1992), pp.58-60. 